This is a self-archived version of an original article. This version may differ from the original in pagination and typographic details.

Author(s): Salo, Age; Uibu, Krista; Ugaste, Aino; Rasku-Puttonen, Helena

Title: The challenge for school-based teacher educators : establishing teaching and supervision goals

Year: 2019

Version: Accepted version (Final draft)

Copyright: ㄷ 2019 Teacher Development

Rights: In Copyright

Rights url: http://rightsstatements.org/page/InC/1.0/?language=en

Please cite the original version:

Salo, A., Uibu, K., Ugaste, A., \& Rasku-Puttonen, H. (2019). The challenge for school-based teacher educators : establishing teaching and supervision goals. Teacher Development, 23(5), 609-626. https://doi.org/10.1080/13664530.2019.1680426 
Title Page With Author Details

\title{
The Challenge for School-based Teacher Educators: Establishing Teaching and Supervision Goals
}

\author{
Author Names \\ Age Salo $^{a^{*}}$, Krista Uibu ${ }^{\mathrm{a}}$, Aino Ugaste ${ }^{\mathrm{b}}$, Helena Rasku-Puttonen ${ }^{\mathrm{c}}$ \\ Department, University, City, Country \\ ${ }^{a}$ Institute of Education, University of Tartu, Tartu, Estonia \\ ${ }^{b}$ School of Educational Sciences, Tallinn University, Tallinn, Estonia \\ ${ }^{c}$ Department of Teacher Education, University of Jyväskylä, Jyväskylä, Finland
}

\section{Full correspondence details for the corresponding author}

Age Salo. Tel.: +372-56-956-297

Hugo Treffner Gymnasium, Munga 12, Tartu 51007, Estonia

E-mail address: age.salo@htg.tartu.ee

\section{Notes on contributors}

Age Salo $(\mathrm{PhD})$ is a teacher of Estonian language and literature in the Hugo Treffner Gymnasium (Estonia). Her main research interests are teachers' beliefs, effective teaching practices and teacher's professional development.

Krista Uibu is a professor of primary education in the Institute of Education at University of Tartu (Estonia). The wider fields of her research are teachers' teaching practices and their dynamics, teaching styles and instructional approaches; relationships between primary school teachers' teaching practices and their pupils' language competence. She has a long-standing involvement in large research projects and is a member of the senior research staff.

Institute of Education

University of Tartu, Salme 1a, Tartu 50090, Estonia

E-mail address: krista.uibu@ut.ee

\begin{abstract}
Aino Ugaste is a professor in the Institute of Educational Sciences at Tallinn University (Estonia). The field of her research has been connected with the study of teachers' professional development, early childhood education and parenting educational values. She has participated in several international research projects which aim is to analyse children's learning, teachers' teaching practices.

School of Educational Sciences

Tallinn University, Uus-Sadama 5, Tallinn 10120, Estonia

E-mail address: ainosaar@tlu.ee
\end{abstract}

Helena Rasku-Puttonen is a professor emerita at the Department of Teacher Education, University of Jyväskylä (Finland). Her areas of interest in research include learning communities, collaboration and social interaction at school and working life contexts.

P.O. Box 35

FI-40014 University of Jyväskylä, Finland

Department of Teacher Education

E-mail address: helena.rasku-puttonen@jyu.fi 


\title{
The Challenge for School-based Teacher Educators: Establishing Teaching and Supervision Goals
}

\author{
Age Salo $^{\mathrm{a}^{*}}$, Krista Uibu ${ }^{\mathrm{a}}$, Aino Ugaste ${ }^{\mathrm{b}}$, Helena Rasku-Puttonen $^{\mathrm{c}}$ \\ ${ }^{a}$ Institute of Education, University of Tartu, Tartu, Estonia \\ ${ }^{b}$ School of Educational Sciences, Tallinn University, Tallinn, Estonia \\ ${ }^{c}$ Department of Teacher Education, University of Jyväskylä, Jyväskylä, Finland
}

\begin{abstract}
School-based teacher educators should be able to set goals in two roles - as a teacher and as a supervisor of student teachers. The purpose of the study was to investigate school-based teacher educators' teaching and supervising goals and to identify how teachers in the role of supervisors perceived university expectations. Thematic analysis indicated that teachers have difficulty establishing goals for themselves as teachers and supervisors. Their teaching goals proceeded from curricula and focused on their pupils' cognitive development, whilst their perceptions about supporting pupils' social development were vague. Teachers were unaware of what exactly universities expected of them as supervisors, and believed that providing teaching models for student teachers as a main supervisory goal. It is necessary to offer options to encourage cooperation between teachers and universities and maintain supervisors' professional development.
\end{abstract}

Keywords: school-based teacher educators; teaching goals; supervising student teachers; teacher-university cooperation; thematic analysis

\section{Introduction}

Competing trends in teacher education programmes and the question of balance between school and university involvement in initial teacher training have highlighted concerns over how effectively teachers actually support student teachers' development during in-school training (Aubusson and Schuck 2013; Hodgson 2014; Van Velzen and Volman 2009). In many European countries, including Estonia, in-school placement of student teachers has been increasing (European Commission/EACEA/Eurydice 2015). Transforming teacher education from university to a school-based system heightens the teachers' responsibility to prepare student 
teachers for their future work (White, Dickerson, and Weston 2015). As school-based teacher educators (SBTEs), they must be prepared to perform two roles: teaching subject content to the pupils and supporting a student teacher's teaching skills (Langdon 2017; White 2014). However, some evidence reveals that teachers lack the time needed to supervise students (Hodgson 2014) and prioritise their pupils' academic progress over supporting student teachers in the instructional process (Ambrosetti 2014; Jaspers, Meijer, Prins, and Wubbels 2014).

As supervisors, teachers should set an example to student teachers by supporting both the cognitive and social development of pupils. Nevertheless, some teachers have difficulty setting teaching goals related to measurable outcomes and focus on teaching practices without considering the purpose of their teaching (Vaughn 2014). Since the development of pupils' knowledge and academic success is easily evaluated, teachers are more inclined to support pupils' cognitive than social development (Lim and Chai 2008; OECD 2014; Uibu and Kikas 2014). The reason might be that teachers are not confident regarding the development of the pupils' social skills (Zwaans, ten Dam, and Volman 2006).

To achieve initial training requirements, SBTEs should be familiar with university expectations of them as supervisors (Butler and Cuenca 2012) and receive training in supervising from universities ( $\mathrm{Ng}$ and Chan 2012). However, SBTEs do not always have the qualification and sufficient skills needed to supervise student teachers (Hodgson 2014; Uibu, Salo, Ugaste, and Rasku-Puttonen 2017; Young and MacPhail 2014). Research in Australia, Hong Kong, and Ireland has concluded that a lack of cooperation between universities and schools adversely effects the professional development of SBTEs ( $\mathrm{Ng}$ and Chan 2012; Uusimaki 2013; Young and MacPhail 2014). Thus, an internationally acknowledged need exists to study teachers' willingness for supervising students in order to improve the quality of teacher training.

Attention needs to be paid to the SBTEs' role in initial teacher training, as several countries have a shortage of highly qualified teachers in the global labour market (Aubusson and Schuck 2013; Ben-Peretz, Kleeman, Reichenberg, and Shimoni 2010). Teacher education in the countries where pupils achieve very good results in international surveys, such as PISA and TIMSS, get more attention than that of other countries. Presumably something in the teacher education of those countries could be taken as a model. Estonian pupils whose results have topped world-wide educational surveys (OECD 2016) have also achieved the highest level among pupils of former socialist countries. Therefore, Estonian teachers are well qualified to throw light on these results. However, it is recognised that the initial teacher training system of Estonia has been less studied than other high-performing countries (Révai 2018). Investigation 
of Estonian teachers, who set goals in two roles - as a teacher and as a supervisor of student teachers - will help improve an entire initial teacher training system in the world. Thus, the purpose of this study was to examine school-based teacher educators' teaching and supervising goals and to identify how these teachers perceive university expectations in their role as supervisors.

\subsection{Establishing Teaching Goals}

To establish teaching for supporting the holistic development of pupils, it is important to set appropriate teaching goals (Uibu and Kikas 2014), which proceed from curricula as well as from teachers' understanding of teaching (Teague et al. 2012). If teachers seek to comprehensively advance their pupils' education, their task is to consider both social and cognitive development goals. However, several factors, such as insufficient knowledge about the goal-setting process, experience to formulate the goals and lack of time complicate the process of establishing teaching goals for teachers (Camp 2017).

In the instruction, teachers are expected to promote different cognitive processes of pupils, such as remembering, understanding, implementation and analysis (Perry, Donohue, and Weinstein 2007). Teachers aim to establish a link between the existing and new skills of pupils. Teachers who concentrate on delivering rules or improving remembering skills should also pay attention to the development of pupils' critical thinking skills (Ford and Wargo 2012). In the process of teaching, it is important to concentrate on explaining, reasoning and drawing conclusions (Hong and Vargas 2015), as well as to initiate discussions between students and encourage them to express their own opinions (Uibu et al. 2017). Also, associating new information with the existing knowledge develops pupils' comparison and contrasting skills (Teague et al. 2012).

Moreover, focusing on students' cognitive skills may inhibit their social skills, such as coping in the social environment and abiding by social norms (Mikami et al. 2012). Some teachers seem to believe that the encouragement of social skills is to help pupils adapt to changes and cope in the society (Zwaans et al. 2006). For others, social skills help pupils to achieve requirements, represented in the curriculum (Zwaans et al. 2008). Accordingly, teachers should explain how students have to communicate with their peers, to use practices for facilitating co-operation between pupils, and teach them how to appreciate another persons' opinion. However, teachers who recognise the development of social skills in the students are not qualified enough to develop them further (Vaughn 2014). 


\subsection{University Expectations and Supervision Goals for Teachers}

Supervising comprises a complex set of goals, not only a delivery of knowledge or sharing experience in teaching (Loughran 2014). It relies on guidance of student teachers towards relating theoretical knowledge with practices (Goodwin and Kosnik 2013). Teachers are expected to have good teaching skills and be able to conduct lessons according to goals (O’Dwyer and Atli 2015; Van Velzen and Volman 2009). They also should be able to provide student teachers with novel teaching models and give feedback in order to help them understand their learning needs and weaknesses (Butler and Cuenca 2012; Nilsson and van Driel 2010).

Depending on their qualification and perception of supervision, SBTEs may focus on different goals (Clarke, Triggs, and Nielsen 2014; Langdon 2017). For example, in Australia teachers tend to assume the aim of supervision is to provide student teachers with advice and emotional support for conducting lessons (Ambrosetti 2014). In Israel, SBTEs focus more on the modelling of teaching and on associating pedagogical knowledge with practices in order to learn from the process of supervision (Ben-Peretz et al. 2010). A study conducted in Ireland indicated that teachers prefer to observe student teachers and give feedback to enhance their teaching competence (Young and MacPhail 2014). When teachers do not facilitate student teachers by applying knowledge about teaching acquired at university into practice, the supervision goals may remain unachieved (Van Velzen and Volman 2009).

Teachers expect cooperation and shared responsibility between the school and the university; in contrast, universities consider SBTEs to be independent as supervisors (Uusimaki 2013). Cooperation with universities supports teachers' professional development and leads to changes in both teaching and supervising (Ambrosetti 2014; White et al. 2015). However, poor communication between universities and SBTEs can lead to misunderstandings regarding supervision goals. If universities do not direct teachers in the supervision process, then teachers may rely on their colleagues' support (Young and MacPhail 2014) or student teachers' notions (Clarke et al. 2014), instead of conscious pedagogical options (Nilsson and van Driel 2010). In studying Dutch SBTEs, Van Velzen and Volman (2009) found that teachers who rely on their personal teaching experience may lack the ability to explain their activities or connect them with theoretical teaching concepts.

Several collaboration forms between universities and SBTEs, such as university supervisors' visits to schools, courses and workshops for teachers, and teachers' involvement in the elaboration of teacher education programmes could be applied (Van Velzen 2013). The Finnish and Dutch teacher education systems offer several positive examples of co-operation between schools and universities (Sahlberg 2010; Van Velzen 2013). Following the example of 
these countries teacher training schools of Estonian universities also have started to look for ways to support SBTEs.

\subsection{Context of Estonian initial teacher education}

Good results achieved by the Estonian pupils in the international surveys (e.g., the Programme for International Student Assessment; PISA), have confirmed the effectiveness of Estonian teachers' work (OECD 2016). The level of Estonian teacher education is high, thanks to substantial changes in the national educational policy. New professional standards that highlight the teachers' ability to act more purposefully taking into account the development of pupils and social changes, and to cooperate with universities came into force in 2013 (Estonian Qualifications Authority 2013; Révai 2018). In order to enhance the co-operation between schools and universities an up-to-date network of school practice, so-called Model of Innovation Schools, was founded in Estonia. The teachers belonging to the network are responsible for supervising teacher training students and to participate in the development of education in general (Pedaste et al. 2014).

Changes made in the teacher education aim to modernise teaching in the manner that helps to enhance the skills that pupils need in life. According to the National Curriculum for Basic Schools (2011/2014) teaching should aim, besides the cognitive development and academic excellence of children, also to support their social development. However, studies have shown that teachers tend to prioritise the cognitive development of pupils and do not give enough support to the enhancement of their social skills (Uibu and Kikas 2014; Uibu et al. 2017). Less teaching activities that support co-operation between pupils, such as teamwork and project based learning, are used in the study process (OECD 2014). It also appears that the study goals are often too general and teachers are not able to competently explain how they will achieve the set goals (Okas, van der Schaaf, and Krull 2016). Besides, the Estonian Lifelong Learning Strategy 2020 refers to the problem that the theoretical knowledge of teachers to their teaching goals and teaching activities within the teaching process has to be solved (Ministry of Education and Research 2014). Those teachers participating in the Estonian teacher training programmes have a strong influence on the training of future teachers, as they work as SBTEs for the initial teacher education (Poom-Valickis and Löfström 2014).

The teacher's work is, by its nature, ideological (Goodson 2014) as in addition to the changes in everyday teaching practices teachers have to be well informed about the changes in the society and initial teacher training in universities. Adjusting to changes may be difficult for Estonian teachers because of norms, rules and beliefs inherited from the previous social 
formation and due to the substantially higher average age of 48 for Estonian teachers compared to other OECD countries (OECD 2014). When trying to adjust to new concepts of learning and trends of teaching, teachers feel uncertainty and lack of clear guidance which was common in Soviet schools. Since SBTEs are responsible for helping students to associate the knowledge acquired in the university with their school experience, they have to assist students in preparing lessons, as well as to observe and analyse students' actions in the classroom (Pedaste et al. 2014). However, only three years of teaching experience and, if possible, passing a supervisor's training course offered by universities are required from teachers who supervise in-school training (Sarv 2014). This might be the reason why SBTEs may not be ready to fulfil the expectations of student teachers.

\subsection{The Aim and Research Questions}

The aim of the study was to investigate school-based teacher educators' goals when they teach pupils and supervise student teachers and to identify how teachers in the role of supervisors understand university expectations. The following research questions were established:

1) What are the goals set by SBTEs to promote pupils' development?

2) How do SBTEs perceive university expectations of them as supervisors of student teachers?

3) What kinds of goals do SBTEs establish for supervising student teachers during inschool training?

\section{Methods}

\subsection{Participants}

This study was conducted as part of research focused on the assessment of school-based teacher educators' (SBTEs') teaching and supervising competence. Based on the purposeful sampling, 16 teachers (15 women and 1 man) were selected from previous studies (Salo et al. 2015; Uibu et al. 2017). These teachers were appropriate for the examination of SBTEs' perceptions about teaching and supervision goals since they all taught various subjects at university teacher training schools (in grades 1 to 6). All selected teachers had supervision experience with student teachers $(\min =1$ year, $\max =30$ years, $M=12)$ and had participated in a one-year mentor training programme for SBTEs, organised by the universities. Teachers' average age was 47 years $(\min =32, \max =63)$ and their teaching experience varied from 7 to 40 years $(M=22)$. The teachers participated voluntarily in the study and for the purpose of confidentiality, specific codes (e.g., T4, T11) are used instead of their names when presenting the study results. 


\subsection{Data Collection}

Semi-structured interviews were used to collect the data. Topics were chosen and research questions were established according to the results of earlier studies (Salo et al. 2015; Uibu et al. 2017) and the aims of the present study. The pilot interviews with three teachers were carried out. The most appropriate questions for revealing teachers' goals related to teaching pupils and supervising student teachers were identified.

The first part of the interview included questions related to SBTEs' teaching goals and teaching practices proceeding from them (e.g., what goals have you set in the age group of students whom you teach?). In the second part, the questions were focused on SBTEs' perceptions about university expectations (e.g., what do you think the university expects of you as a supervisor?). The aim of the third part was to explore how SBTEs understand their goals of supervising student teachers (e.g., which goals do you keep in mind when supervising student teachers?). At the end of the interviews, teachers were given the opportunity to elaborate on some of their previous answers.

All interviews, agreed upon with the teachers via email or phone, were carried out at a time suitable for the teachers in their classrooms. The aims of the interviews were explained to the teachers and background data were collected (subjects taught by the teacher, teaching and supervising experience etc.). The average duration of the interviews was 46 minutes ( $\max =63$; $\min =32$ ). The total length of the interviews was 160 pages.

\subsection{Data Analysis}

To examine the teachers' goals, thematic analysis was used, as this method is both flexible and provides a profound and complex account of the data (Braun and Clarke 2006). The first author transcribed all the interviews word by word, then listened to the recordings again to check the accuracy of the transcriptions. The same author cross-checked the transcriptions to confirm its relevance to the research questions. Then, meaningful segments (phrases or sentences) were marked and initial codes were generated. After a discussion with the co-authors, a coding frame was developed; in order to refine the codes and increase the trustworthiness of the study, authors coded all interviews independently. Further, codes representing similar content were grouped under the sub-themes (Figure 1).

Figure 1. Example of the formation of the themes. 


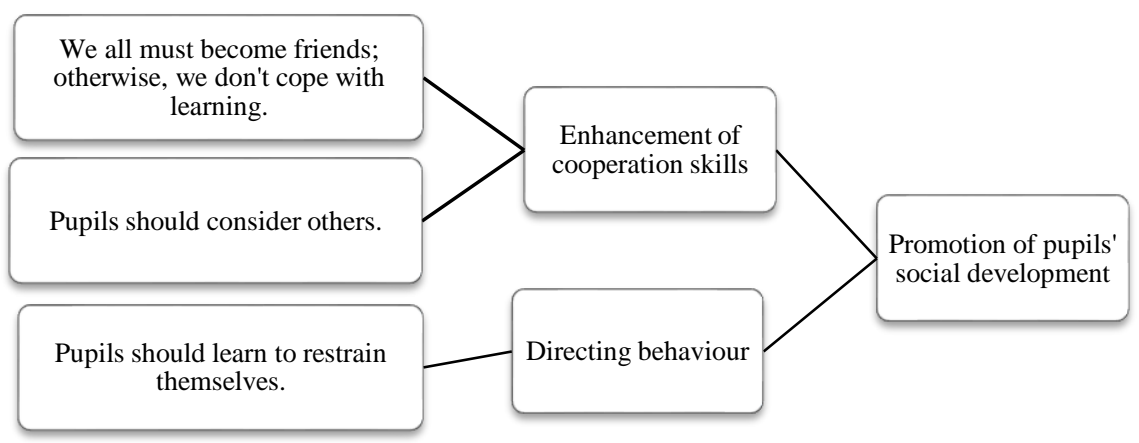

The next step involved identifying themes and reviewing and refining the main themes. The authors reached a consensus and a data table was developed, with the codes grouped into subthemes under the main themes. Finally, the main themes and sub-themes were structured according to the research questions.

In order to increase trustworthiness of the study enough time has been allocated to complete all phases of the analysis adequately (see Braun and Clarke 2006). The researchers consulted with each other every stage of the data analysis and discussed the resulting interpretations. After a thorough discussion, a consensus was reached among all three authors.

\section{Results}

The following results will be presented in relation to their research questions and in three sections. In the first section, the goals addressed to promote the cognitive development and social development of pupils, are reported. The school-based teacher educators' (SBTEs') perception of the university expectations of them as supervisors are presented in the second section. SBTEs' understanding of the supervising goals of student teachers are described in the last part of the results. An overview of the main and sub-themes of interviews is presented in table 1. Excerpts from the teachers' interviews are used to illustrate the results of thematic analysis.

Table 1. Main themes and sub-themes according to the research questions.

\begin{tabular}{llllll}
\hline Q1: Teaching goals & Q2: University expectations & & Q3: Supervision goals \\
\hline Main themes & Main themes & Associating theory & Giving feedback \\
\hline $\begin{array}{l}\text { Promotion of } \\
\text { students' } \\
\begin{array}{l}\text { cognitive } \\
\text { development }\end{array}\end{array}$ & $\begin{array}{l}\text { Promotion of students } \\
\text { social development }\end{array}$ & $\begin{array}{l}\text { Willingness to } \\
\text { supervise }\end{array}$ & $\begin{array}{l}\text { Establishing } \\
\text { teaching } \\
\text { models }\end{array}$ & $\begin{array}{l}\text { Guidance in the } \\
\text { instructional } \\
\text { process }\end{array}$ & $\begin{array}{l}\text { Professional } \\
\text { development } \\
\text { of SBTE }\end{array}$ \\
\hline Sub-themes & teachers & & Sub-themes & \\
\hline
\end{tabular}




\begin{tabular}{|c|c|c|c|c|c|c|c|}
\hline $\begin{array}{l}* \text { Acquisition of } \\
\text { knowledge } \\
* \text { Implementa- } \\
\text { tion of } \\
\text { knowledge } \\
\text { *Following } \\
\text { curriculum } \\
\text { requirements }\end{array}$ & $\begin{array}{l}\text { *Enhancement of } \\
\text { cooperation skills } \\
\text { *Enhancement of } \\
\text { behavioural skills } \\
\text { *'Good person' }\end{array}$ & $\begin{array}{l}\text { * Uncertainty in } \\
\text { formulating } \\
\text { expectations } \\
\text { *Complexity of } \\
\text { teacher training } \\
\text { system }\end{array}$ & $\begin{array}{l}\text { *Providing teaching } \\
\text { examples } \\
* \text { Coping with } \\
\text { problems in the } \\
\text { teaching process } \\
\text { *Becoming familiar } \\
\text { with the school } \\
\text { organisation }\end{array}$ & $\begin{array}{l}\text { *Supporting } \\
\text { students' self- } \\
\text { reflection skills } \\
\text { * Giving feedback } \\
\text { *Lack of } \\
\text { opportunities for } \\
\text { feedback }\end{array}$ & $\begin{array}{l}\text { *Implementa- } \\
\text { tion of } \\
\text { teaching } \\
\text { activities } \\
\text { *Communica- } \\
\text { tion with } \\
\text { pupils }\end{array}$ & $\begin{array}{l}\text { *Establishing } \\
\text { teaching goals } \\
* \text { Utilisation of } \\
\text { subject } \\
\text { knowledge } \\
\text { *Supporting of } \\
\text { the co-operatior } \\
\text { readiness of } \\
\text { students }\end{array}$ & $\begin{array}{l}* \text { Knowledge } \\
\text { about new } \\
\text { methods } \\
\text { *Opportunity } \\
\text { to receive } \\
\text { feedback }\end{array}$ \\
\hline
\end{tabular}

\subsection{Teachers'goals in developing pupils}

School-based teacher educators described a variety of teaching goals with regard to promoting pupils' development. Generally, teachers tended to focus more on the cognitive development of pupils, but their explanations in terms of pupils' social development remained superficial.

To promote the pupils' cognitive development, teachers emphasised the acquisition of subject-related knowledge. They described it as a system in which the pupils move progressively from a lower cognitive level to a higher one. All teachers highlighted the value of practical knowledge, associating the learning of facts and rules with activities demonstrating the precise application of knowledge. They were of the opinion that pupils should be able to analyse tasks independently and make decisions themselves. Teachers explained how they initiated classroom discussions to promote pupils' analytical skills and how to find different options to solve problems. Encouraging pupils to apply knowledge via reasoning was highlighted as well. Interviewee T10 stated: "You still challenge them by asking "why" and "how". You make them look for reasons."

The following teaching goal - to explain a subject clearly and understandably to pupils - emerged from the interviews. Teachers often apply real-world examples to give students a better understanding and relationship between what is learned in the classroom and what is experienced in real life.

A child had to describe a forest. She said a couple of sentences and nothing else came to her mind. I told the child to close her eyes and imagine that she was in the forest - to see what was there and what did it look like. The child started to say all the correct things. When she opened her eyes she asked: did I say the right things? My goal was to make pupils to see the associations. (T5)

In order to enhance the pupils' cognitive development, teachers kept in mind the goals established in the national curriculum and descriptions of students' academic outcomes. Teachers are familiar with these requirements and are expected to achieve the desired results. Nevertheless, they admitted that covering every topic required in the curriculum is complicated since it is important to discuss extra-curricular issues of interest with their pupils. Teachers also considered that it is important to cover the extra-curricular issues that interest their pupils. 
To promote pupils'social development, teachers felt that pupils should acquire the skills needed for communication. The development of listening skills and the creation of the learning environment that supports oral skills were considered as factors that support co-operation skills. According to some teachers, the goals related to teaching subject-specific content may, therefore, be sometimes pushed into the background:

For two months, I spent the best part of the lesson teaching children to listen to, and communicate with each other - I was only able to begin teaching the subject after a month.

At the same time teachers were worried about increasing behavioural problems that required particular attention in cases of pupils with lower learning motivation. Teachers likewise described their efforts to develop pupils' behavioural skills, due to concerns about increasing behavioural problems as a result of low motivation for studying. Pupils have to understand what is acceptable behaviour and what changes are needed. Teachers considered it is particularly important to pay attention to pupils' behaviour in their initial school years: "If there is discipline and students are considerate towards each other, we can move on to the subject." (T11).

Based on teachers' descriptions of how pupils' social development is promoted, the results were inconclusive. The teachers used expressions like 'good person' or 'nice person' to describe how pupils would develop. Whereas teaching goals related to the cognitive development originate mainly from the curriculum, goals associated with the social development of pupils proceed more from social expectations. Thus, the teachers considered the impact of social norms on everyday life while developing social adaptability among their pupils.

\subsection{University Expectations for School-Based Teacher Educators}

Answering the question: "What do you think the university expects of you as a supervisor?" turned out to be complicated for many teachers. Phrases such as "I do not know (exactly)" or "It seems to me" were frequently used. According to SBTEs they lack a precise guidance material on how to organise students' school practise. Probably that is why presumptions, instead of a clear knowledge of what universities expect from SBTEs prevailed in the teachers' answers. From the subsequent interviews three main themes regarding the teachers' perceptions about university expectations, became apparent.

Firstly, describing their willingness to supervise student teachers, a multifaceted picture from teachers' responses appeared. Teachers had often taken the supervision of students without warning and without any prior training. However, working in an up-to-date practice school (so- 
called innovation school) means there is an obligation to train future teachers, and it is rather difficult for teachers to refuse that obligation.

Headmaster [...] says that I have to supervise. The first reaction is always that I don't have time to do it besides my main tasks. Still, I also have to find time for delving into students' issues. (T8)

In addition to the lack of preparation of SBTEs to supervise students the complexity of the renewed training system also makes the understanding of the expectations of universities quite difficult. SBTEs said that they have understood that school practice consists of several stages and students observe lessons for different reasons. However, this system has not been introduced to them. Teachers pointed out that students were unable to explain their exact observation goals. Teachers were of the opinion that guidance materials compiled by universities would help them to understand what universities expect from them as supervisors.

Students are sent to the school but there are no clear written instructions explaining the teaching role. If they are available, they are minimal. Over the years I have been critical of this lack of information. (T9)

Some teachers, however, were more aware of the universities expectations. They mentioned offering positive school experience to students, giving supportive feedback and assistance in analysing lessons as their supervision goals. All of these teachers had passed school-based teachers education training organised by a university. Teachers also admitted that they try to understand what universities expect from them as supervisors by exploring students' practice tasks.

Secondly, in the opinion of the teachers, associating student teachers' theoretical knowledge with practice is the second general expectation established for teachers by the universities. Teachers thought that they are supposed to help student teachers to build a bridge between theory and everyday school life. To broaden students' understandings, teachers conduct model lessons and implement various teaching methods, for example group work and instructional games. However, teachers were not able to tell what kind of concepts of learning they are expected to follow and what sort of teaching activities to implement. According to interviewees, students should see 'something interesting' in model lessons.

Teachers also thought that universities expect them to shape the students' ability to cope with problems faced in the instructional process, for example, teach them how to react to inappropriate behaviour of pupils or how to resolve conflicts between pupils. Many teachers are of the opinion that the task of a SBTE is to introduce the teacher's work in the manner that ensures that a student will be capable of managing independently as a teacher.

The main thing is to let young people know what school life really means. So, when they 
graduate and go to work, it would not be a leap in the dark, but would know what sort of problems are awaiting them and how to cope with them. (T11)

As an exception, one teacher pointed out that a university expects that a SBTE should introduce student teachers to school records and working routines. No other teacher described such exceptional perceptions.

Thirdly, in the teachers' opinion, student teachers who do not have teaching competence, should have the opportunity to experience and provide feedback of both success and failure throughout the practice. Universities seem to expect that SBTEs develop students' selfreflection skills through positive feedback so that students could understand better their strengths and weaknesses. In the teachers' estimation they are expected to tolerate students' mistakes with patience and benevolence in order to support their motivation to become teachers. At the same time, teachers pointed out the contradiction between the expectations of the university and their own views. Interviewee T5 stated: "During the reflection training at the university we were told that we should be given very positive feedback all the time." Teachers are of the opinion that the university expects modest criticism from SBTEs, however, teachers think that serious problems such as poor subject-related knowledge of students, lack of establishing contact with pupils or an inability to run a tight ship in the classroom should be pointed out. Therefore, negative feedback is sometimes necessary. If students receive only positive feedback they will not learn to assess their shortcomings in knowledge and skills.

Although, teachers considered that feedback is the most effective way to support student teachers, they complained that there was a lack of time to provide sufficient feedback. Some teachers said that they give suggestions mainly during breaks or via email. Teachers argued that university supervisors have more significant role than SBTEs in advising student teachers. As interviewee T5 commented: "When the university supervisor goes to the classroom, they analyse the lesson very thoroughly together with the student. I can't do that because normally my class continues right after." Moreover, in the teachers' opinion, their knowledge about providing feedback, compared to university supervisors, is being 'not so scientific'.

\subsection{Supervision Goals of School-based Teacher Educators}

In contrast to perceptions, the university modified their expectations to SBTEs, teachers' understandings of their supervision goals during in-school training. Teachers determined their goals in two ways: first, to establish teaching models for student teachers and to guide them in the instructional process, and second, to encourage their professional development. 
All teachers believed that establishing teaching models for student teachers is necessary, although descriptions of model lessons varied. Some teachers provide lessons that students observe more thoroughly than regular lessons; others did not see a difference between them. SBTEs focussed on the needs of pupils and considered the expectations of students to be less important. For example, interviewee T13 stated: “I definitely don't change many things. That would be strange. After all, I'm giving a lesson to pupils not students.” Teachers generally attempted to implement contemporary teaching practices so that student teachers would recognise in the classroom what they had learned at university. Several teachers emphasised that the goal of model lessons was not to guide students towards imitating teachers.

Teachers also endeavoured to set a pattern of how to communicate with pupils. They believed that students should see how a teacher asserts herself/himself in a classroom, and how he/she manages the class and maintains the discipline.

Sometimes pupils need to be reprimanded, you cannot close your eyes to the fact that some of the pupils don't feel like cooperating today. A teacher should tell the pupils that you are disrupting the lesson and that it is not allowed. (T11)

By setting a pattern teachers wanted to encourage students and show them how to cope with different classroom situations.

With reference to guiding students in the instruction process SBTEs expressed their concern about students' poor ability to establish teaching goals. Teachers emphasised that student teachers do not cope very well with establishing teaching goals, while the goals are schematic and often cannot be associated with the activities carried out in the classroom. Too few, or on the contrary, too many similar activities are planned into a single lesson. As a result "varying of different activities during a lesson has disappeared" (T1). On the other hand, establishing teaching goals will help student teachers to manage with time and assess instructional practices that they are planning. According to many SBTEs the planning of teaching activities related to the goals of a lesson depends on the pupils' development. These teachers were concerned about the student teachers' skill to use age-appropriate instructional practices. Therefore, SBTEs have to explain to students that there are pupils with different abilities and skills in the class and during the planning of the lesson, everyone's needs has to be considered.

When a student is carrying out a lesson, a SBTE apprehends the level of subject-related knowledge of the student. Teachers were worried about the quality of teaching when they discovered that some students were unaware of certain rules and facts. However, several teachers were of the opinion that it is not SBTEs' responsibility to fill gaps in the subject-related 
knowledge of students during their in-school training. Half of respondents wanted student teachers to be responsible for the quality of lessons even if they only gave a few of them during practice.

Teachers found a strong connection between quality of lessons, pupils' development and cooperation with student teachers. Discussions during the planning of lessons help students to generate ideas and choose teaching activities that are suitable for particular pupils. In order to ensure the quality of teaching, teachers considered it necessary to disrupt the lesson if they saw any problems and they expected the students to accept such intervention. Speaking about cooperation, T5 said:

Very often simple advice is enough: what are the activities that work and which are the ones that don't work; what takes more and what takes less time. It's good if she [student teacher] co-operates with a supervisor.

Teachers were of the opinion that students should ask for help more often during their school practice so that teachers could offer them appropriate assistance and ensure the quality of teaching.

The professional development of SBTE was realised as one of the benefits of supervising student teachers. When teachers observe and analyse the student's performance in class, it also supports the teacher's professional growth. Teachers appreciated the opportunity to both observe how students applied novel methods acquired at the university and generated new ideas on how to enhance teaching. For example, T10 remarked: "You do learn yourself, too, quite a lot from a student. They somehow enrich, and bring something new to school life."

Supervising has been seen as a good opportunity to assess oneself from another's perspective and receive feedback. When students analyse their lessons, teachers also start to reason more, what and why they have done certain things in their class. According to teachers, supervising has changed the way they teach pupils and the materials they use. Likewise, they have incorporated ideas suggested by student teachers. Supervising students prevents teachers from becoming too cosy at their job:

I'll be honest, I'd no longer need to check anything when teaching the fourth grade, but then you'll become lazy, there needs to be some kind of factor which forces yourself to work.

In addition, two teachers, who wanted to learn something new themselves, are being kept updated on what is happening at the university. Teachers wish to keep up with innovations in teaching theories in order to offer even more effective support to student teachers who undertake their teaching practice at school. 


\section{Discussion}

School-based teacher educators (SBTEs) whose responsibilities include educating pupils as well as assisting students on their way to becoming teachers should be able to establish wellgrounded teaching and supervising goals to meet the required university expectations of them as supervisors. The study revealed that SBTEs mainly focused on pupils' cognitive development and had problems pursuing social development goals. It also appeared that SBTEs did not perceive clearly what universities expected from them as supervisors and, therefore, relied rather on their personal perception and experience than a clear knowledge of their supervision goals. SBTEs' main goal in model lessons for student teachers was to establish good teaching models.

First, we were interested in the goals that SBTEs established to promote a pupils' development. With regard to the cognitive development, teachers focused on goals, defined in the National Curriculum for Basic Schools (2011/2014). Many teachers described subjectrelated knowledge and skills, e.g., how to implement knowledge into real life situations, analyse and solve problems. Teachers tend to focus on pupils' knowledge because they are of the opinion that supplying pupils with this knowledge gives them the opportunity to teach effectively (Lim and Chai 2008). On the other hand, to develop pupils' cognitive skills it is necessary to initiate problem-based learning and discussions in the classroom (Ford and Wargo 2012; Teague et al. 2012). These goals were also emphasised by some teachers in the current study. Accordingly, teachers skilfully described different goals of cognitive development. This may be caused by the high expectations prevailing in the Estonian society that pupils should achieve very good results in international benchmarking (see OECD 2014, 2016 for Estonian students' results). However, apparently, knowing the goals established by a curriculum does not always mean that teachers follow and achieve these goals in the teaching process (Hong and Vargas 2015).

Some inconsistencies in teachers' goal setting for pupils' development were revealed. While teachers demonstrated good knowledge when explaining the cognitive development goals of pupils, they were less confident when describing the social development goals, and relied more on their personal opinions and value judgements. Similar to the study by Vaughn (2014) the teachers who lacked opportunities (e.g. lack of time) and skills to give meaning to their activities often admitted that they had problems with formulating their goals. However, the responses of most of the teachers showed that they wished to enhance the communication skills of pupils but they were worried about the pupils' behavioural habits. These social skills are highly valued among teachers mainly for the reason that they support pupils in studies as 
well as in following social norms (Jaspers et al. 2014; Zwaans et al. 2006).

A second question was how teachers perceive university expectations of them as supervisors during in-school training. This study revealed that many of the SBTEs are not well enough prepared to supervise students and that lack of instructional materials for supervising. The same tendency also has become evident in studies carried out in other countries (Hodgson 2014; Young and MacPhail 2014). The reasons why universities do not sufficiently support SBTEs may be the common notion that supervisors as experienced teachers will be able to cope with supervising on their own (Uusimaki 2013; White 2014). The lack of precise guidance material issued by universities in Estonia is systematic of the tendency to increase the responsibility of supervisors in the training process of future teachers. At the same time, the SBTEs who have not been specially trained to supervise students have to help student teachers to associate theory with educational practice and cope with a diversity of problems (Ben-Peretz et al. 2010; Goodwin and Kosnik 2013) as well as provide teaching examples (White et al. 2015). Nevertheless, if universities do not adequately support SBTEs, the quality of in-school training may be reduced (Hodgson 2014).

Our study also shows that the expectations of universities and the notion of SBTEs on supervision may not coincide. Teachers are of the opinion that universities expect them to give mainly positive feedback to student teachers by supporting their self-reflection skills. However, SBTEs think that sometimes more criticism is needed in the process of supervising students. The teachers who were well aware of the principles of feedback considered that it is not always possible to carry them out in practice as pointing out only the positive would not sufficiently support the development of students. The main reason why SBTEs saw problems in feedback may be due to the lack of co-operation with university supervisors. The studies conducted in Australia (Uusimaki 2013) and Ireland (Young and MacPhail 2014) have revealed that SBTEs expect university supervisors to explain the supervision goals and support teachers in supervising. The dissonance between the notions of universities and SBTEs could be caused by the fact universities focus more on formal institutional co-operation with schools and pay less attention to teachers who supervise students (Ng and Chan 2012). Hodgson (2014) agreed that universities do not always take into account the need of SBTEs to receive feedback on their work as supervisors, as well as to improve their supervision skills.

In response to the third question, we found that the teachers' main goal for supervising was an establishment of teaching models for student teachers. Earlier studies have indicated that teachers expect student teachers to follow their example (Van Velzen and Volman 2009); however, the current study revealed that teachers did not presume that students would conduct 
lessons the same way they had. According to White (2014), SBTEs expect, that student teachers analyse SBTEs' model lessons from the critical point of view and, when teaching, apply knowledge that they have acquired at the university. Although the SBTEs who participated in our study supported the independence of student teachers when they were teaching, they were unhappy that the subject-related knowledge of students acquired at university was not always good enough and consequently students lacked the skill of establishing teaching goals. However, SBTEs also had difficulties in establishing teaching goals. Contrary to the previous studies (Uusimaki 2013) half of the SBTEs did not think that they were responsible for improving the subject-related knowledge of students. They were worried about their pupils because of the quality of lessons during in-school training, but not for the development of the future teachers.

Following, it has emerged that teachers appreciated the supervising experience as a benefit for professional development. For example, reflecting on supervision experience enables teachers to better understand their goals and the aims of teaching practices (O'Dwyer and Atli 2015) as well as to perceive better the role of SBTE (Ambrosetti 2014). Teachers also may gain new ideas by observing student teachers' lessons (White et al. 2015). Mainly those SBTEs who were interested in the theoretical knowledge acquired by students at the university, saw their role as a supervisor as an opportunity to develop as a teacher. However, they did not explain how cooperation with student teachers developed their supervising skills.

Some limitations, related to the method, should be discussed. In the study, teachers' descriptions about their goals and expectations were analysed. However, it should be noted that teachers' reported claims may differ from their real practice (Teague et al. 2012). Therefore, in order to specify teachers' goals in relation to teaching and supervising, video recordings of lessons could be used in further studies. Besides, in this study, only teachers were interviewed. It would be advantageous to interview student teachers in order to broaden the understanding of SBTEs' goals in the field of teaching and supervising.

The results of this study demonstrated that SBTEs' goals for teaching pupils or supervising student teachers are comparable with regard to both pupils' and student teachers' readiness to apply knowledge into practice and gain cooperation skills. Teachers seemed to be convinced that cooperation helps them to ensure a supportive learning environment and fill in the gaps in students' knowledge and teaching skills (Nilsson and van Driel 2010; Van Velzen and Volman 2009). Interpreting similarities in teachers' perceptions of their teaching and supervision goals may help teachers find a balance between their teaching and supervising. 


\section{Conclusions}

The results of this study, concentrating on teachers' perceptions about teaching and supervising goals and university expectations to school-based teacher educators, presented a challenge to Estonian SBTEs as has been reported in other studies: how to combine effectively the roles of teacher and SBTEs in-school training (see Ambrosetti 2014; White et al. 2015). Although, there is an evidential trend towards increasing the role of SBTE in teacher education, teachers are not well-prepared to perform this role. In order to promote high-quality, versatile teaching and supervising, SBTEs should be trained to employ activities that help develop pupils' social skills and to give students relevant feedback. Even if the main responsibility for carrying out in-school training is assigned to SBTEs, universities should offer systematic support to teachers to close the gap between teachers' perceptions of supervising and university expectations. It is also essential to carry out further studies on ways to improve cooperation between teachers and universities, and support SBTEs' professional development.

\section{References}

Ambrosetti, A. 2014. "Are You Ready to be a Mentor? Preparing Teachers for Mentoring PreService Teachers." Australian Journal of Teacher Education 39 (6): 30-42.

Aubusson, P., and S. Schuck. 2013. “Teacher Education Futures: Today’s Trends, Tomorrow's Expectations." Teacher Development 17 (3): 322-333.

Ben-Peretz, M., S. Kleeman, R. Reichenberg, and S. Shimoni. 2010. "Educators of Educators: Their Goals, Perceptions and Practices." Professional Development in Education 36 (1): 111-129.

Braun, V., and V. Clarke. 2006. "Using Thematic Analysis in Psychology.” Qualitative Research in Psychology 3 (2): 77-101.

Butler, B. M., and A. Cuenca. 2012. "Conceptualizing the Roles of Mentor Teachers in Student Teaching." Action in Teacher Education 34 (4): 296-308.

Camp, H. 2017. “Goal Setting as Teacher Development Practice. " International Journal of Teaching and Learning in Higher Education 29 (1): 61-72.

Clarke, A., V. Triggs, and W. Nielsen. 2014. "Cooperating Teacher Participation in Teacher Education: A Review of the Literature." Review of Educational Research 84 (2): $163-202$.

Estonian Qualifications Authority. 2013. Professional Standard: Teacher EstQF Level 7. Accessed February 10 , 2017. http://www.kutsekoda.ee/en/kutsesysteem/tutvustus/kutsestandardid_eng 
European Commission/EACEA/Eurydice. 2015. The Teaching Profession in Europe: Practices, Perceptions, and Policies. Eurydice Report. Luxembourg: Publications Office of the European Union.

Ford, M. J., and B. M. Wargo. 2012. "Dialogic Framing of Scientific Content for Conceptual and Epistemic Understanding." Science Education 96 (3): 369-391.

Goodson, I. F. 2014. "Investigating the Life and Work of Teachers." Estonian Journal of Education 2 (2): 28-47

Goodwin, A. L., and C. Kosnik. 2013. "Quality Teacher Educators = Quality Teachers? Conceptualizing Essential Domains of Knowledge for those Who Teach Teachers." Teacher Development 17 (3): 3343-46.

Hodgson, J. 2014. " Surveying the Wreckage: The Professional Response to Changes in Initial Teacher Training in the UK." English in Education 48 (1): 7-25.

Hong, J., and P. Vargas. 2016. “Science Teachers' Perception and Implementation of InquiryBased Reform Initiatives in Relation to Their Beliefs and Professional Identity." International Journal of Research Studies in Education 5 (1): 3-17.

Jaspers, W. M., P. C. Meijer, F. Prins, and T. Wubbels. 2014. "Mentor Teachers: Their Perceived Possibilities and Challenges as Mentor and Teacher." Teaching and Teacher Education 44: 106-116.

Langdon, F. J. 2017. "Learning to Mentor: Unravelling Routine Practice to Develop Adaptive Mentoring Expertise.” Teacher Development 21 (4): 528-546.

Lim, C. P., and C. S. Chai. 2008. "Teachers' Pedagogical Beliefs and Their Planning and Conduct of Computer-Mediated Classroom Lessons." British Journal of Educational Technology 39 (5): 807-828.

Loughran, J. 2014. "Professionally Developing as a Teacher Educator." Journal of Teacher Education 64 (4): 1-13.

Mikami, A. Y., M. S. Griggs, M. M. Reuland, and A. Gregory. 2012. "Teacher Practices as Predictors of Children's Classroom Social Preference.” Journal of School Psychology 50 (1): $95-111$.

Ministry of Education and Research. 2014. The Estonian Lifelong Learning Strategy 2020, $\begin{array}{llllll}\text { Tallinn. } & \text { Accessed } & 1 & \text { November } & 1, & 2018 .\end{array}$ https://www.hm.ee/sites/default/files/estonian_lifelong_strategy.pdf

National Curriculum for Basic Schools. 2011/2014. Riigi Teataja. Accessed November 1, 2018. https://www.hm.ee/en/national-curricula-2014

Ng, S., and E. Chan. 2012. „School-University Partnership: Challenges and Visions in the 
New Decade.“ Global Studies of Childhood 2 (1): 38-56.

Nilsson, P., and J. van Driel. 2010. "Teaching Together and Learning Together-Primary Science Student Teachers' and Their Mentors' Joint Teaching and Learning in the Primary Classroom." Teaching and Teacher Education 26 (6): 1309-1318.

O’Dwyer, J. B., and H. H. Atli. 2015. "A Study of In-Service Teacher Educator Roles, with Implications for a Curriculum for Their Professional Development.” European Journal of Teacher Education 38 (1): 4-20.

OECD (The Organization for Economic Cooperation and Development). 2014. TALIS 2013 Results. An International Perspective on Teaching and Learning. Accessed February 10, 2017. http://dx.doi.org/10.1787/9789264196261-en

OECD. 2016. PISA 2015 Results (Volume I): Excellence and Equity in Education. Paris: OECD Publishing. Advance online publication. doi:10.1787/9789264266490-en.

Okas, A., M. Van der Schaaf, and E. Krull. 2016. “Õpetaja tegevus tunnis: õpilaste hinnangud ja nende kooskõla õpetajate arusaamadega." [Students' Perception of Their Teachers' Behaviour in the Classroom and Its Coherence with Teachers' Own Understandings]. Estonian Journal of Education 4 (1):195-225.

Pedaste, M., K. Pedaste, K. Lukk, P. Villems, and R. Allas. 2014. "A Model of Innovation Schools: Estonian Case-Study.” Procedia-Social and Behavioral Sciences 112: 418427.

Perry, K. E., K. M. Donohue, and R. S. Weinstein. 2007. “Teaching Practices and the Promotion of Achievement and Adjustment in First Grade." Journal of School Psychology 45 (3): 269-292.

Poom-Valickis, K., and E. Löfström. 2014. "Pikiuuring õpetajaks õppijate professionaalse identiteedi kujunemisest" [A Longitudinal Study of the Development of the Professional Identity of Student Teachers]. Estonian Journal of Education 2 (1): 241-271.

Révai, N. 2018. "What difference do standards make to educating teachers? A review with case studies on Australia, Estonia and Singapore.” OECD Education Working Papers 174. Paris: OECD Publishing.

Sahlberg, P. 2010. The Secret to Finland's Success: Educating Teachers. Stanford, CA: Stanford Center for Opportunity Policy in Education.

Salo, A., K. Uibu, A. Ugaste, and H. Rasku-Puttonen. 2015. "The Question about Effective Teaching: Educational Students' and School-Based Teacher Educators' Beliefs about Effective Teaching Practices." Procedia-Social and Behavioural Sciences 191: $2203-2212$. 
Sarv, E-S. 2014. “A Status Paper on School Teacher Training in Estonia.” Journal of International Forum of Educational Research 1 (2): 106-158.

Teague, G. M., V. A. Anfara Jr., N. L. Wilson, C. B. Gaines, and J. L. Beavers. 2012.

"Instructional Practices in the Middle Grades: A Mixed Methods Case Study." NASSP Bulletin 96 (3): 203-227.

Uibu, K., A. Salo, A. Ugaste, and H. Rasku-Puttonen. 2017. "Beliefs about Teaching Held by Student Teachers and School-Based Teacher Educators." Teaching and Teacher Education 63: 396-404.

Uibu, K., and E. Kikas. 2014. "Authoritative and Authoritarian-Inconsistent Teachers' Preferences for Teaching Methods and Instructional Goals." Education 3-13 42 (1): $5-22$.

Uusimaki, L. 2013. “Empowering Pre-Service Teacher Supervisors' Perspectives: A RelationalCultural Approach Towards Mentoring." Australian Journal of Teacher Education 38 (7): 42-58.

Van Velzen, C. 2013. Guiding Learning Teaching. Towards a Pedagogy of Work-based Teacher Education. Amsterdam: VU University.

Van Velzen, C., and M. Volman. 2009. "The Activities of a School-Based Teacher Educator: A Theoretical and Empirical Exploration." European Journal of Teacher Education 32 (4): $345-367$.

Vaughn, M. 2014. “Aligning Visions: Striking a Balance between Personal Convictions for Teaching and Instructional Goals." The Educational Forum 78 (3): 305-313.

White, E. 2014. "Being a Teacher and a Teacher Educator - Developing a New Identity?" Professional Development in Education 40 (3): 436-449.

White, E., C. Dickerson, and K. Weston. 2015. "Developing an Appreciation of What It Means to be a School-Based Teacher Educator." European Journal of Teacher Education 38 (4): 445-459.

Young, A. M., and A. MacPhail. 2014. "Irish Physical Education Teachers' Experiences of Learning to Become a 'Teacher of Teachers'." The Open Sports Science Journal 7 (2): 98-105.

Zwaans, A., G. ten Dam, and M. Volman. 2006. "Teachers' Goals Regarding Social Competence.” European Journal of Teacher Education 29 (2): 181-202.

Zwaans, A., I. van der Veen, M. Volman, and G. ten Dam. 2008. "Social Competence as an Educational Goal: The Role of the Ethnic Composition and the Urban Environment of the School." Teaching and Teacher Education 24 (8): 2118-2131. 